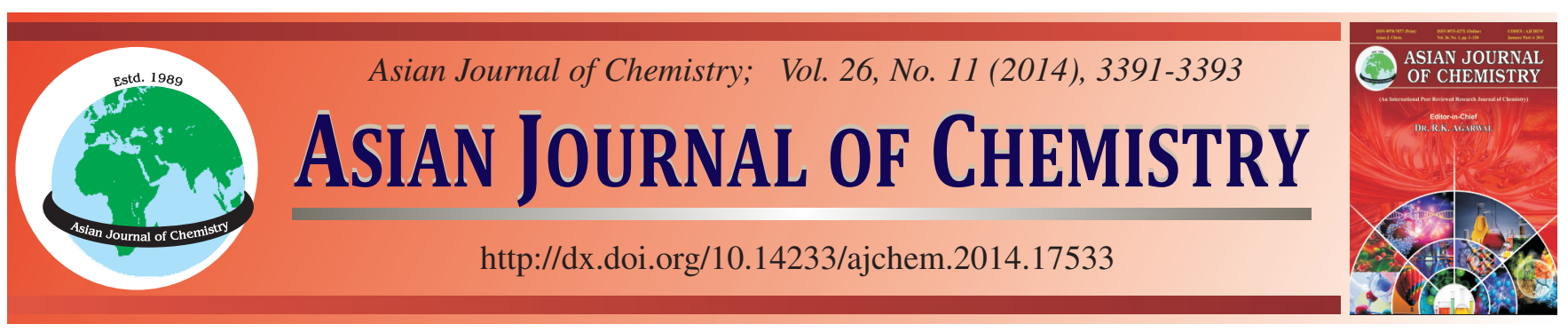

\title{
Study of Indoor Room Environment Based on Demand of Aerobic Respiration
}

\author{
WANG-Hu SuN ${ }^{1, *}$ and XuE-FenG CHEN $^{2}$
}

${ }^{1}$ College of Civil Science and Engineering, Yangzhou University, Jiangsu, P.R. China

${ }^{2}$ Anhui Broadcasting Movie and Television College, Hefei, Anhui, 230011, P.R. China

*Corresponding author: Fax: +86 551 63854038; Tel: +86 15062822588; E-mail: whsun@yzu.edu.cn

This paper aims to study the area size of a living room from the angle of satisfying a person's aerobic respiration. By calculating the daily oxygen demand and normal breathing oxygen mass in a room sealed, the paper deduces a relationship formula between the room area and the normal oxygen supply time. As a result, the minimum area of a healthy room can be calculated. In an overly small room, one may be subject to hypoxia and the health will be affected in case of inadequate ventilation. Uniquely, the article obtains the minimum area of living room from the angle of aerobic respiration.

Keywords: Architectural design, Bedroom, Use area, Oxygen, Respiration, Hypoxia. L

\section{INTRODUCTION}

In the current residential design in China, the miniaturization trend of total gross floor area of dwelling is significant. However, based on the modern medicine, providing that the oxygen content is lower than $18 \%$, the oxygen intake for human body is inadequate, which attributes to the overly low oxygen in blood and unsaturated hemoglobin and further certain new changes occurred on cells of all human tissues, presenting the corresponding anoxic symptoms (Fig. 1) due to inadequate oxygen supply ${ }^{1}$. During the application of heating in winter and air condition in summer, people always fall asleep in the bedroom with the door and windows closed, as a result, the oxygen content from the air in the room is gradually decreasing along with the continuous breath. The oxygen content is related to the bedroom volume, therefore the paper tries to deduce the min. net area of a bedroom for architectural design in accordance with the relevant principles of human aerobic respiration.

Human daily oxygen demand: Respiration is the gas exchange process between the living organisms and external environment. While a person breaths, the oxygen in the air will be absorbed into pulmonary alveolus and diffused in blood and integrated with hemoglobin, then carried to the whole body by the blood circulation and finally taken in and utilized by cells and tissues. The respiration usually refers to the aerobic respiration, including three stages ${ }^{2}$ :

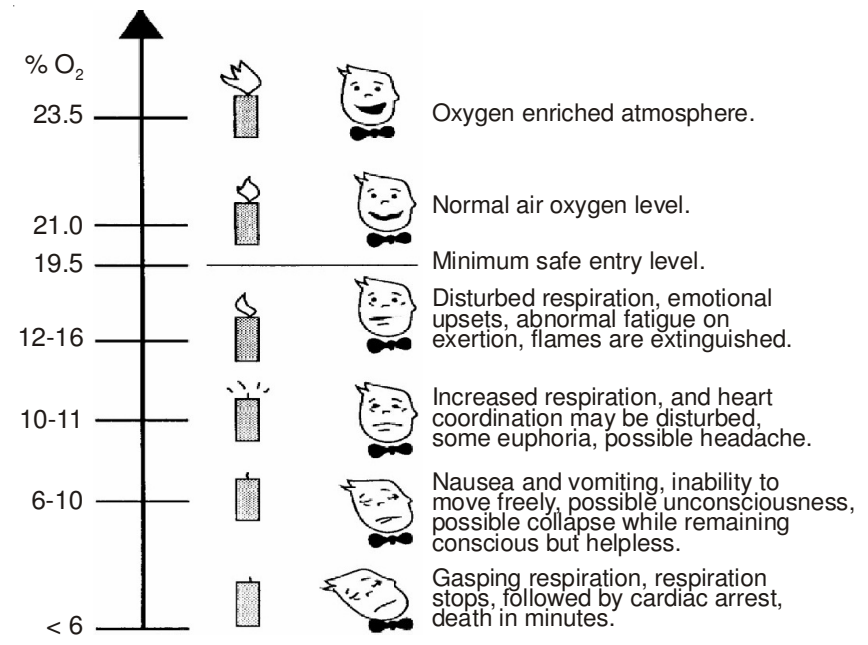

Fig. 1. Symptoms of hypoxia

Stage 1: No need for oxygen. One molecule of glucose from the matrix of the cytoplasm decomposes into two molecules of pyruvate and produces $4[\mathrm{H}]$ (activated hydrogen), releasing a small amount of energy, a part of which is used for ATP synthesis. The equation shows:

$$
\mathrm{C}_{6} \mathrm{H}_{12} \mathrm{O}_{6} \rightarrow 2 \mathrm{C}_{3} \mathrm{H}_{4} \mathrm{O}_{3}+4[\mathrm{H}]+\text { small amount of (2ATP) }
$$

Stage 2: Also no need for oxygen. After the pyruvate goes into the matrix of mitochondrion, two molecules of pyruvate and six water molecules of hydrogen have been all taken off 
with $20[\mathrm{H}]$ in total, releasing a small amount of energy, a part of which is used for ATP synthesis and produces small amount of energy. The equation shows:

$2 \mathrm{C}_{3} \mathrm{H}_{4} \mathrm{O}_{3}+6 \mathrm{H}_{2} \mathrm{O} \rightarrow 20[\mathrm{H}]+6 \mathrm{CO}_{2}+$ small amount of (2ATP)

Stage 3: This stage requires for oxygen participation. On the inner membrane of the mitochondrion, the total $24[\mathrm{H}]$ from the previous two stages unites with $6 \mathrm{O}_{2}$ absorbed from external environment to form water, releasing a large quantity of energy, a part of which is used for ATP synthesis and produces a lot of energy. The equation shows:

$24[\mathrm{H}]+6 \mathrm{O}_{2} \rightarrow 12 \mathrm{H}_{2} \mathrm{O}+$ a large quantity of energy (34ATP)

The total equation is obtained by adding all previous equation:

$$
\begin{aligned}
\mathrm{C}_{6} \mathrm{H}_{12} \mathrm{O}_{6}+6 \mathrm{H}_{2} \mathrm{O} & +6 \mathrm{O}_{2} \rightarrow 6 \mathrm{CO}_{2}+12 \mathrm{H}_{2} \mathrm{O} \\
& + \text { a large quantity of energy (38ATP) }
\end{aligned}
$$

ATP (adenosine-triphosphate), its condensed structural formula is $\mathrm{A}-\mathrm{P} \sim \mathrm{P} \sim \mathrm{P}$, chemical formula $\mathrm{C}_{10} \mathrm{H}_{16} \mathrm{~N}_{5} \mathrm{O}_{13} \mathrm{P}_{3}$ and molecular weight 507.184. Almost all energy required by human body is supplied by ATP, whose total amount in human body is only 0.1 moles. A person's daily energy requires hydrolyzing 100-150 mole ATP with equivalence to $50-75 \mathrm{~kg}$ and also to his body weight.

The mole weight of $\mathrm{O}_{2}$ is $32 \mathrm{~g} / \mathrm{mol}$ and based on the total equation, $\mathrm{O}_{2}$ required for producing 100 mol ATP shows as follows:

$$
\begin{aligned}
& 100 \times 6 / 38=15.79(\mathrm{~mol}) \\
& 32 \times 100 \times 6 / 38=505(\mathrm{~g})
\end{aligned}
$$

Therefore, human daily oxygen demand ranges from 505$758 \mathrm{~g}$.

Respiratory oxygen consumption: The air mainly consists of $\mathrm{O}_{2}, \mathrm{CO}_{2}$ and $\mathrm{N}_{2}$, whose proportions are relatively constant and only $\mathrm{O}_{2}$ and $\mathrm{CO}_{2}$ have biological significance. The steam in the inhalant air, exhalant air and alveolar air are in saturated status with the volume percents and partial pressure of all air is presented in Table- 1 .

$\mathrm{N}_{2}$ has no increase or decrease in the course of respiration, but its percentage changes relatively due to the percentage changes of $\mathrm{O}_{2}, \mathrm{H}_{2} \mathrm{O}$ and $\mathrm{CO}_{2}$. The air quantity inhaled and exhaled in a quiet manner every time by a normal adult is around $500 \mathrm{~mL}$. According to the gas equation:

$$
\mathrm{pV}=\mathrm{nRT}
$$

where: p: gas pressure, $\mathrm{Pa}$; V: volume, $\mathrm{m}^{3}$; R: gas constant with the value of $8.314472 \mathrm{~J} /(\mathrm{K} \mathrm{mol})$; $\mathrm{T}$ : absolute temperature, $\mathrm{K} ; \mathrm{n}$ : mole number and $\mathrm{m}=\mathrm{n} \cdot \mathrm{M}$, in which $\mathrm{M}$ is mole weight, $\mathrm{m}$ refers to weight $(\mathrm{g})$ and oxygen mole weight $\mathrm{M}=$ $32 \mathrm{~g} / \mathrm{mol}$.
So:

$$
\mathrm{m}=\frac{\mathrm{pVM}}{\mathrm{RT}}
$$

In the case of room temperature is $25^{\circ} \mathrm{C}$ and the temperature of exhalant air is $36{ }^{\circ} \mathrm{C}$, based on the eqn. 2 and Table-1, the $\mathrm{O}_{2}$ weight absorbed by a person during each breath is:

$$
\begin{aligned}
& \Delta \mathrm{m}=\mathrm{m}_{\text {in }}-\mathrm{m}_{\mathrm{ex}} \\
= & \frac{\mathrm{p}_{\mathrm{in}} \mathrm{VM}}{\mathrm{RT}_{\mathrm{in}}}-\frac{\mathrm{p}_{\mathrm{ex}} \mathrm{VM}}{\mathrm{RT}_{\mathrm{ex}}} \\
= & 0.0288(\mathrm{~g})
\end{aligned}
$$

That is to say, under normal circumstance, each breath requires to consume $0.0288 \mathrm{~g} \mathrm{O}_{2}$ from the air.

Room oxygen supply: Generally speaking, any environment with oxygen content lower than $20.9 \%$ is defined as anoxic environment and oxygen content at $19.5 \%$ is regarded as the minimal safe level.

Now a days, the average net height of bedrooms is $2.8 \mathrm{~m}$. Because the furniture in the bedroom, such as bed, bedside table and even wardrobe, occupy a certain room space, net volume of the respirable air in the bedroom is commonly smaller than the bedroom volume. For easy to formula derivation, the air net volume rate (shown as a) defined here refers to the percentage of the respirable air net volume and the volume surrounded by the inner surfaces of the room. The percentage is generally $95 \%$ and the goes smaller with more furniture in the room and vice versa ${ }^{3}$.

Because the water vapour in the exhalant gas stays in a saturated state and its content is far higher that the one in the air, in the case of without considering water vapor condensation, increasing the water in the human body, the volume of the exhalant air should be larger than the air volume absorbed by human body. In other words, after person breaths for a long time, the air pressure in a room sealed will be a bit higher than the outside of the room. When the bedroom is under the normal pressure, it is very limited to exchange air with other rooms through the crack of the door. Moreover, due to the good airtightness of present windows, in the case of without considering the oxygen infiltration amount by window crack and the temperature changes before and after sleep, the oxygen content will decrease from 20.9-19.5\% when a person sleeps in such bedroom and the $\mathrm{O}_{2}$ amount $(\Delta \mathrm{m})$ absorbed by a person through respiration could be calculated according to eqn. 2 as follows:

$$
\Delta \mathrm{m}=\frac{\mathrm{p}_{1} \mathrm{VM}}{\mathrm{RT}}-\frac{\mathrm{p}_{2} \mathrm{VM}}{\mathrm{RT}}=\left(\mathrm{p}_{1}-\mathrm{p}_{2}\right) \frac{\text { ahsM }}{\mathrm{RT}}
$$

TABLE-1

VOLUME PERCENTS AND PARTIAL PRESSURE OF ALL AIR AT SEA LEVEL

\begin{tabular}{cccccccccc}
\hline \multirow{2}{*}{ Gas name } & \multicolumn{2}{c}{ Atmosphere } & \multicolumn{2}{c}{ Inhalant Air } & \multicolumn{2}{c}{ Exhalant Air } & \multicolumn{2}{c}{ Alveolar Air } \\
\cline { 2 - 9 } & $\begin{array}{c}\text { Volume } \\
(\%)\end{array}$ & $\begin{array}{c}\text { Partial pressure } \\
(\mathrm{kpa})\end{array}$ & $\begin{array}{c}\text { Volume } \\
(\%)\end{array}$ & $\begin{array}{c}\text { Partial pressure } \\
(\mathrm{kpa})\end{array}$ & $\begin{array}{c}\text { Volume } \\
(\%)\end{array}$ & $\begin{array}{c}\text { Partial pressure } \\
(\mathrm{kpa})\end{array}$ & $\begin{array}{c}\text { Volume } \\
(\%)\end{array}$ & $\begin{array}{c}\text { Partial pressure } \\
(\mathrm{kpa})\end{array}$ \\
\hline $\mathrm{O}_{2}$ & 20.84 & 21.15 & 19.67 & 19.86 & 15.7 & 15.96 & 13.6 & 13.83 \\
$\mathrm{CO}_{2}$ & 0.04 & 0.04 & 0.04 & 0.04 & 3.6 & 3.59 & 5.3 & 5.32 \\
$\mathrm{~N}_{2}$ & 78.62 & 79.4 & 74.09 & 74.93 & 74.5 & 75.28 & 74.9 & 75.68 \\
$\mathrm{H}_{2} \mathrm{O}$ & 0.5 & 0.49 & 6.2 & 6.25 & 6.2 & 6.25 & 6.2 & 6.25 \\
Total & 100 & 101.08 & 100 & 101.08 & 100 & 101.08 & 100 & 101.08 \\
\hline
\end{tabular}

This table is quoted from Table 5-2 in Page 146 of Physiology in version 7 edited by Zhu Da-nian. 
where: V: respirable air volume, V: a h S, S refers to room net area and $h$ refers to the net height of the room; a: air net volume rate, generally $95 \% ; \mathrm{p}_{2}: \mathrm{O}_{2}$ partial pressure at the min. safe oxygen content of $19.5 \%, \mathrm{p}_{2}=19.5 \% \mathrm{p}$, p refers to atmosphere pressure; $\mathrm{p}_{1}: \mathrm{O}_{2}$ partial pressure in the bedroom before sleep and $\mathrm{p}_{1}=20.9 \%$ p calculated by $\mathrm{O}_{2}$ normal content in the air.

Due to $\mathrm{O}_{2}$ content in the atmosphere basically stays at $20.9 \%$, it could be calculated in eqn. 3 by substituting the constants $\mathrm{M}$ and $\mathrm{R}$ :

$$
\begin{gathered}
\Delta \mathrm{m}=32 \times(20.9 \%-19.5 \%) \text { a p h S }(8.314 \mathrm{~T})^{-1} \\
=53.88 \times 10^{-3} \times \mathrm{a} \mathrm{p} \mathrm{h} \mathrm{S} \mathrm{T}^{-1}
\end{gathered}
$$

Supposed that the bedroom net area $\mathrm{S}$ is $6 \mathrm{~m}^{2}$, net height $\mathrm{h}$ is $2.65 \mathrm{~m}$ (floor height $2.8 \mathrm{~m})$, temperature $25^{\circ} \mathrm{C}(\mathrm{T}=273.15$ $+25=298.15 \mathrm{~K}$ ), air net volume rate a $95 \%$ and atmosphere pressure $\mathrm{p}=101325 \mathrm{~Pa}$, the result from eqn. 4 as:

$\Delta \mathrm{m}=53.88 \times 10^{-3} \times 95 \% \times 101325 \times 2.65 \times 6 / 298.15$

$$
=276.58(\mathrm{~g})
$$

It shows that, based on the previous human daily oxygen demand ranges from 505-758 g, a person should not stay in such a room with the door and windows closed more than $12 \mathrm{~h}$.

A normal person respires 14-18 times/min during sleeping and based on the low value 14 times selected and $0.0288 \mathrm{~g} \mathrm{O}_{2}$ consumption for each respiration, the time (hours) of the oxygen for maintaining the normal respiration for human in the bedroom sealed should be:

$$
\begin{aligned}
\mathrm{t} & =\Delta \mathrm{m}(0.0288 \times 14 \times 60)^{-1} \\
& =53.88 \times 10^{-3} \times \mathrm{a} \mathrm{p} \mathrm{h} \mathrm{S}\left(24.19 \mathrm{~T}^{-1}\right. \\
& =2.228 \times 10^{-3} \times \mathrm{a} \mathrm{p} \mathrm{h} \mathrm{S} \mathrm{T}
\end{aligned}
$$

where, $t$ refers to the time (h) of the oxygen for maintaining the normal respiration for human in the bedroom sealed.

To simplifying the calculation, the other variables except for $\mathrm{S}$ may select their mean values: $\mathrm{a}=95 \%, \mathrm{p}=101325 \mathrm{~Pa}$, $\mathrm{h}=2.8 \mathrm{~m}, \mathrm{~T}=298.15 \mathrm{~K}$, therefore, eqn. 5 may be simplified approximately to:

$$
\mathrm{t}=2 \mathrm{~S}
$$

\section{Conclusion}

The hours for a single person staying in a living room sealed exceed inappropriately twice of the area of the room, otherwise, he/she will be in danger of anoxia. The sleeping duration for normal adults ranges from $6-8 \mathrm{~h}(10 \mathrm{~h}$ for the elder and children, even longer for infants), plus the time in the bedroom before and after sleeping, roughly calculating by $10 \mathrm{~h}$, the net area of a single bedroom should not be smaller than $6 \mathrm{~m}^{2}$ and the one for double bedroom should not be smaller than $10 \mathrm{~m}^{2}$, besides, the bedroom should be daily ventilated. In the cold regions, due to the doors and windows are always closed during the heating period in winter, the infrequent ventilation causes the indoor environment usually in the status of anoxia (the oxygen content lower than $20.9 \%$ ), in view of this situation, the area of the living area should be increased to satisfy the human demand for aerobic respiration and realize the harmony between the architecture and human ${ }^{4}$.

\section{ACKNOWLEDGEMENTS}

The authors thank Yao Jie, Professor of School of Language, Literature and Law, Xi'an University of Architecture and Technology, for her translation of this paper. This article was funded by the Natural Science Foundation of China (51211130119).

\section{REFERENCES}

1. X.-L. Cha and C.-Y. Zhou, Biochemistry, People's Medical Publishing House, Beijing, China, edn. 7, pp 160-162 (2011); ISBN: 978-7-11709688-1.

2. W.-H. Sun, Towards the Harmony Architecture, Hefei University of Technology Publishing House, Hefei, China (2013); ISBN: 978-7-56501440-6.

3. W.H. Sun, Appl. Mechan. Mater, 71, 261 (2011).

4. D.N. Zhu, Physiology, People's Medical Publishing House, Beijing, China, edn 7, pp: 140-147 (2011); ISBN: 978-7-117-09459-7. 